ORIGINAL ARTICLE

\title{
Evaluation of the micropropagation potential of curauá pineapple hybrids for fiber production
}

\author{
Cintia Paula Feitosa SOUZA ${ }^{1,3}$, Everton Hilo de SOUZA ${ }^{1,3}$, Carlos Alberto da Silva LEDO ${ }^{1,2}$, \\ Fernanda Vidigal Duarte SOUZA ${ }^{1,2^{*}}$ \\ Universidade Federal do Recôncavo da Bahia (UFRB), Cruz das Almas, Bahia, Brazil \\ 2 Embrapa Mandioca e Fruticultura (CNPMF), Cruz das Almas, Bahia, Brazil \\ ${ }^{3}$ Coordenação de Aperfeiçoamento de Pessoal de Nível Superior (CAPES), Programa CAPES-EMBRAPA, Braśília - DF, Brazil \\ * Corresponding author: fernanda.souza@embrapa.br
}

\section{ABSTRACT}

Plant fiber is a renewable and biodegradable material that can be used effectively to reinforce various composites. Pineapple hybrids selected for their fiber quality are in the phase of agronomic validation in Brazil by the Embrapa Cassava and Fruits research unit. The selection of a hybrid for large-scale fiber production depends on obtaining a large number of seedlings. This study evaluated the morphogenetic response and propagation potential of eight hybrids of Ananas comosus var. erectifolius, for the purpose of producing high-quality seedlings on a large scale. Stem and crown buds were reduced and placed in MS nutritive medium supplemented with BAP at $0.5 \mathrm{mg} \mathrm{L}^{-1}$, NAA at $0.01 \mathrm{mg} \mathrm{L}^{-1}$ and Phytagel at $2.5 \mathrm{~g} \mathrm{~L}^{-1}$. After 45 days, the number of oxidized, contaminated and surviving buds was determined. Swollen buds and plantlets were transferred to a multiplication medium containing MS sucrose, salts and vitamins. The propagation potential was evaluated based on the geometric growth rate among sub-cultures. The FIB-NEG hybrid presented the best results for the establishment phase (40.28\%). The best propagative potential was obtained from crown buds with the highest values for FIB-EST (3.93), FIB-MIN (3.91) and FIBBOY (3.91) hybrids.

KEYWORDS: Ananas comosus (L.) Merr.; in vitro propagation; lignocellulosic fibers; Poisson log-linear model; geometric growth rates

\section{Avaliação do potencial de micropropagação de híbridos do abacaxi curauá para a produção de fibras}

\section{RESUMO}

A fibra vegetal é uma fonte renovável, biodegradável e de excelente desempenho como reforço em compósitos variados. Híbridos selecionados pela qualidade de suas fibras estão em fase de validação agronômica na Embrapa Mandioca e Fruticultura e sua adoção para produção de fibra em larga escala depende de um elevado número de mudas. Este trabalho teve como objetivo avaliar a resposta morfogenética e o potencial propagativo de oito híbridos de Ananas comosus var. erectifolius, com a finalidade de produzir mudas de qualidade em larga escala. Gemas do caule e coroa foram reduzidas, introduzidas em meio nutritivo MS suplementado com BAP a $0,5 \mathrm{mg} \mathrm{L}^{-1}$, ANA a $0,01 \mathrm{mg} \mathrm{L}^{-1}$ e Phytagel a 2,5 $\mathrm{g} \mathrm{L}^{-1}$. Aos 45 dias foram avaliados o número de gemas oxidadas, contaminadas e sobreviventes. Gemas intumescidas e plantas formadas foram transferidas para o meio de multiplicação contendo sacarose, sais e vitaminas MS. Avaliou-se o potencial propagativo a partir de uma taxa de crescimento geométrico entre subcultivos. O híbrido FIB-NEG (40.28\%) apresentou os melhores resultados em porcentagem para a fase de estabelecimento. O melhor potencial propagativo foi obtido a partir de gemas de coroa, com os valores mais elevados registrados para os híbridos FIB-EST (3.93), FIB-MIN (3.91) e FIB-BOY (3.91).

PALAVRAS-CHAVE: Ananas comosus (L.) Merr.; propagação in vitro; fibras lignocelulósicas; modelo log-linear de Poisson; taxas de crescimento geométrico

CITE AS: Souza, C.P.F.; Souza, E.H. de; Ledo, C.A. da S.; Souza, F.V.D. 2018. Evaluation of the micropropagation potential of curauá pineapple hybrids for fiber production. Acta Amazonica 48: 290-297. 


\section{INTRODUCTION}

Fiber from curauá, Ananas comosus (L.) Merr. var. erectifolius (L.B.Sm.) Coppens \& F. Leal, a pineapple variety native to the Amazon region, is already produced in large scale due to its excellent mechanical strength, besides being biodegradable (Leão et al. 2009). This fiber is used to produce articles for the automotive industry (Zah et al. 2007), the production of polymeric composites (Marinelli et al. 2008; Sena Neto et al. 2013; 2015; 2017; Asim et al. 2015; Souza et al. 2017), and civil engineering products (Rocha et al. 2013). However, the industrial use of curauá was only made possible by the development of a micropropagation protocol to enable production of thousands of seedlings for replanting in large fields (Pereira et al. 2006; 2007).

Curauá hybrids have been selected by genetic improvement as a result of crosses of curauá (Ananas comosus var. erectifolius) with Ananas comosus var. microstachys or Ananas comosus var. bracteatus (Souza et al. 2014), and have already been evaluated regarding suitability of their fibers for industrial use (Sena Neto et al. 2013; 2015; 2017; Souza et al. 2017). The hybrid fibers are a consolidated selection in industrial applications, due to their excellent properties for the development of polymer composites (Sena Neto et al. 2013; 2015; 2017; Souza et al. 2017). For the commercial launch of these materials to meet demand, agronomic validation is necessary, along with the development of processes for large-scale production of seedlings, as has already been established for curauá. However, as the parents forming the curauá hybrids are wild varieties, little is known about the propagation potential of these materials and how they will respond to micropropagation.

Since the genotypic responses to in vitro cultivation conditions are highly variable, different protocols of pineapple micropropagation have been reported (Pasqual et al. 2008; Souza et al. 2012a; 2012b; 2013; Alves et al. 2014; Santos et al. 2015). The Brazilian Agricultural Research Corporation research unit for cassava and fruit (Embrapa Mandioca e Fruticultura) has developed one basic protocol, which produced satisfactory results for various genotypes from its pineapple germplasm bank (AGB-Pineapple) (Souza et al. 2013).

The objective of this study was to assess the morphogenetic response and the propagation potential of curauá hybrids using the standard Embrapa protocol, to enable the production of material for large-scale planting. Considering that these hybrids have wild parents, we evaluated the propagation potential of buds from different regions of the plant.

\section{MATERIAL AND METHODS}

The experiment was conducted with axillary buds, the starting explants in the multiplication process. Buds were removed from the stem and crown of eight curaua hybrids: FIB-NEG (Figure 1a) and FIB-BOY (Figure 1b) (Ananas comosus (L.)
Merr. var. microstachys L.B.Sm. x A. comosus var. erectifolius), FIB-POT (Figure 1c), FIB-MIN (Figure 1d), FIB-EST (Figure 1e), FIB-ROX (Figure 1f) and FIB-CER (Figure 1g) (A. comosus var. erectifolius x Ananas comosus (L.) Merr. var. bracteatus (Lindl.) Coppens \& F.Leal), and FIB-SAI (Figure 1h) (A. comosus var. bracteatus $\mathrm{x}$ A. comosus var. erectifolius).

Leaves were removed from the stem plants and crown to expose the buds. Stems and crowns were washed with water and neutral detergent. The stem of each plant was divided into three regions: i) upper, ii) middle and iii) lower (Figure 1i). Buds located between the first visible bud in contact with the roots and the position of the last root were considered to be from the lower region; those visible between the last root and the point of inflection of the stem were considered to be from the middle region; and the buds from that point to the tip were classified as from the upper region. The crown was not divided into regions due to the short length of its axis (Figure 1i). The buds were excised separately and transferred to laminar flow chambers in autoclaved jars. The asepsis process consisted of immersion of the buds in $70 \%$ alcohol for 5 minutes, to break the surface tension, followed by immersion in a solution of $2.5 \% \mathrm{NaCl}$ in autoclaved distilled water plus three droplets of Tween $20^{\circ}$ for 25 minutes. After this procedure, they were washed three times in autoclaved distilled water. After disinfestation, the excess tissue was removed from each bud before placement in test tubes (one bud per tube) with MS nutritive medium (Murashige and Skoog 1962) supplemented with BAP (6-benzylaminopurine) at $0.5 \mathrm{mg} \mathrm{L}-1$, NAA (naphthaleneacetic acid) at $0.01 \mathrm{mg} \mathrm{L}-1$ and Phytagel $^{\oplus}$ at $2.5 \mathrm{~g} \mathrm{~L}-1$ previously autoclaved at $120{ }^{\circ} \mathrm{C}$ for 20 minutes. The tubes were then distributed randomly in a growth room under incubation conditions of $27 \pm 1{ }^{\circ} \mathrm{C}$, photoperiod of 16 hours and light intensity of $30 \mu \mathrm{mol} \mathrm{m}-2$ $\mathrm{s}-1$, supplied by white fluorescent lamps, where they remained for 45 days (establishment phase).

For the in vitro establishment phase, we used a completely randomized experimental design in an $8 \times 4$ factorial scheme ( 8 hybrids and 4 bud removal regions - upper, middle and lower part of the stem, and crown), with three repetitions, each one composed of a single plant (96 replicates in total). As the source plants came from field conditions, they had a variable number of buds to be used as explant in the multiplication step. After 45 days, we determined the number of oxidized, contaminated and surviving buds (Figure 1j). Data were submitted to two-way ANOVA (F-test). The means of the four collection regions were compared by the Tukey tests at 5\% significance level, and the means of the hybrids were grouped by the Scott-Knott test at 5\% significance level. To satisfy the requirements for analysis of variance, the data on the average number of buds were transformed to and the data on percentage of oxidized, contaminated and surviving buds were transformed to . All the statistical analyses were performed with the $\mathrm{R}$ version 3.4.1 software (R Core Team 2017). 

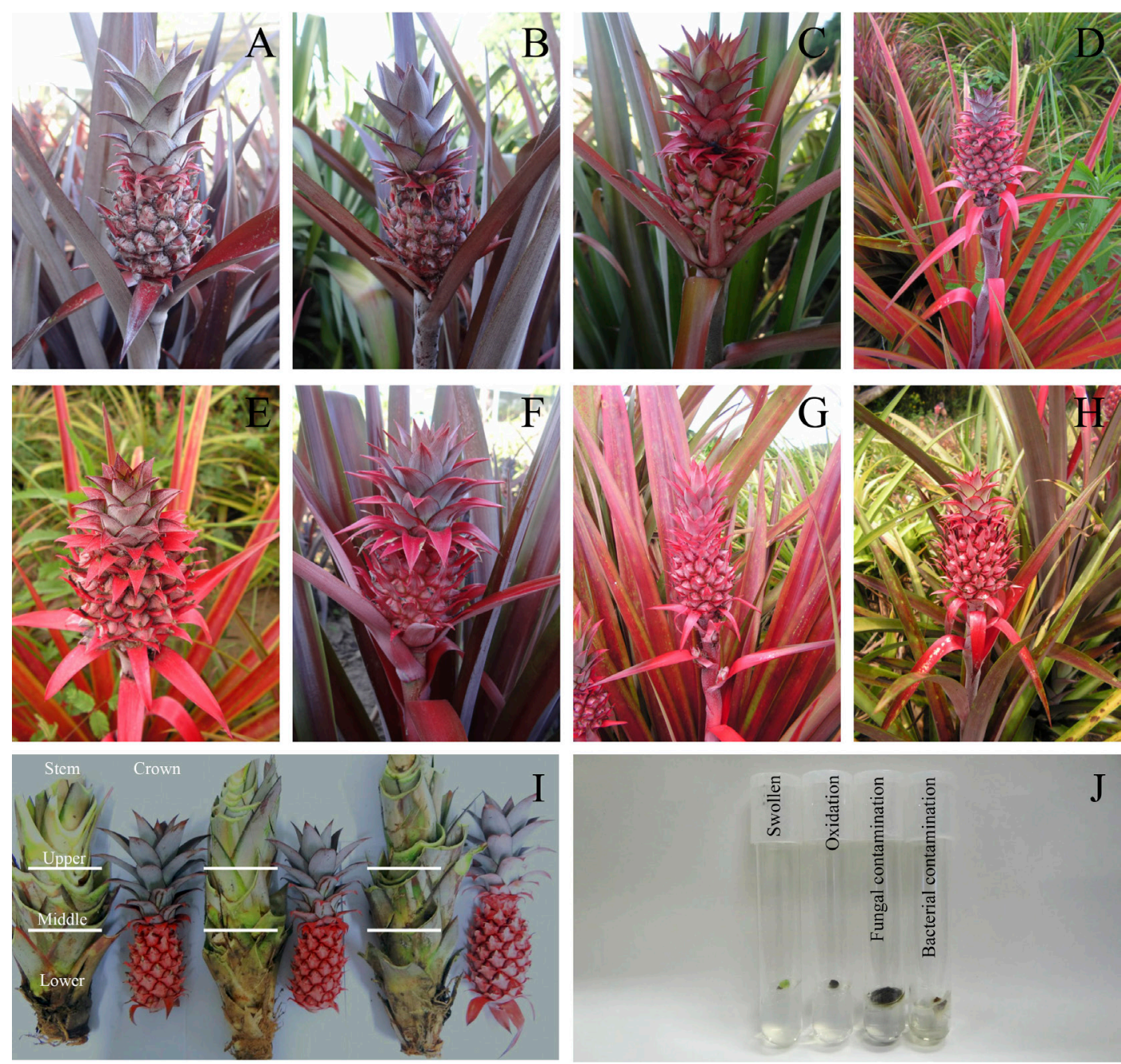

Figure 1. A-H) Pineapple hybrids for fiber production. (A) FIB-NEG and (B) FIB-BOY (Ananas comosus. var. microstachys $x$ A. comosus var. erectifolius); (C) FIB-POT, (D) FIB-MIN, (E) FIB-EST, (F) FIB-ROX and (G) FIB-CER (A. comosus var. erectifolius $x$ Ananas comosus var. bracteatus); (H) FIB-SAl (A. comosus var. bracteatus $x$ A. comosus var. erectifolius). (I) Explants for in vitro establishments from the crown and three different regions of the stem. (J) Swollen buds, with oxidation symptoms and bacterial and fungal contaminations from FIB-POT hybrid in stage of in vitro establishment. This figure is in color in the electronic version.

The swollen buds and plants formed were grouped by treatment and transferred to jars with multiplication medium containing MS salts and vitamins (Murashige and Skoog 1962) supplemented with BAP $0.5 \mathrm{mg} \mathrm{L}^{-1}$, NAA $0.2 \mathrm{mg} \mathrm{L}^{-1}$ and Phytagel $2.5 \mathrm{~g} \mathrm{~L}^{-1}$, a protocol adapted from Souza et al. (2013). The plants had their leaves cut off at the top to induce new shoots. The jars containing the plants were kept in the same incubation conditions as in the establishment phase. Four sub-cultures were performed at intervals of 45 days. Each subculture involved cleaning the roots, removal of the oldest leaves and sectioning of the stem to break the apical dominance and thus favor the formation of new adventitious shoots.

The results of the multiplication phase were also analyzed by fitting a Poisson log-linear model. For this purpose, four hybrids were selected (FIB-NEG, FIB-EST, FIB-MIN and
FIB-ROX) that showed high propagation potential for stem buds, and six hybrids (FIB-NEG, FIB-SAI, FIB-MIN, FIBBOY, FIB-EST and FIB-ROX) that had the best results for crown buds. In this phase we did not distinguish the different regions of the stem due to the high losses from the middle and lower parts. The model used the number of shoots as independent variable (linear and quadratic effects) and the shoot multiplication data as dependent variable, for each of the selected hybrids.

To calculate the propagation potential we used the geometric growth rate (r) between two consecutive subcultures, given by the expression: $r=(t \sqrt{ } / \mathrm{f} / \mathrm{Vi}-1) \times 100$, where: Vf - number of shoots in the subsequent sub-culture; $\mathrm{Vi}$ - number of shoots in the previous sub-culture; and $\mathrm{t}-$ interval of 45 days between each of the four sub-cultures. 


\section{RESULTS}

\section{Establishment phase}

ANOVA resulted in no significant interaction between the factors (hybrids and plant regions), but there was significant variance within the factors $(\mathrm{p}<0.01)($ Table 1$)$. The average number of buds varied significantly among the plant regions (5.29 to 20.46), with the number for the crown buds exceeding the sum of the buds of the three stem regions (Table 2). However, the crown buds also suffered the highest percentage of oxidation (over 50\%), followed by the buds from the upper stem (23\%). In turn, the buds from the lower stem had the highest contamination percentage, probably because of the proximity with the soil, resulting in a very low survival rate (Table 2). Considering oxidation and contamination, there was a significant loss of buds from all the regions, since the highest survival percentages (buds from the crown and upper stem region) were lower than $20 \%$ (Table 2).

There were no significant differences among the hybrids regarding average number of buds. With respect to oxidation, the highest percentages were observed for FIB-SAI, FIB$\mathrm{BOY}$ and FIB-POT, while the highest contamination rates occurred for FIB-CER, FIB-MIN, FIB-EST and FIB-ROX. The survival rates varied from $0.78 \%$ ( 2 buds) for FIB-CER to $40.28 \%$ ( 48 buds) for FIB-NEG, and except for FIB-ROX, the survival rates of the other hybrids were below $12 \%$ (Table 2).

\section{Multiplication phase}

The response to the employed protocol differed among hybrids and between types of starting explants (Table 3). The greatest number of shoots was obtained from the crown buds for all the hybrids except FIB-NEG, and the highest values were recorded for FIB-MIN, FIB-EST and FIB-BOY in the fourth sub-culture. For the stem buds, the hybrids FIB-NEG and FIB-MIN produced the largest average number of shoots. It was not possible to complete all the sub-cultures for the hybrid

Table 1. Summary of the analysis of variance, general averages and coefficients of variation for number of buds and percentages of oxidized, contaminated and surviving buds obtained from different regions of the plant after in vitro establishment of curuá pineapple hybrids.

\begin{tabular}{lccccc}
\hline \multirow{2}{*}{$\begin{array}{l}\text { Source of } \\
\text { variation }\end{array}$} & $\begin{array}{c}\text { Degrees of } \\
\text { freedom }\end{array}$ & $\begin{array}{c}\text { Average } \\
\text { number of buds }\end{array}$ & \multicolumn{4}{c}{ Oxidation Contamination Survival } \\
\hline Plant region & 3 & $24.68^{* *}$ & $23.36^{* *}$ & $0.91^{\text {ns }}$ & $4.01^{* *}$ \\
Hybrids & 7 & $0.34^{\text {ns }}$ & $1.67^{* *}$ & $1.66^{* *}$ & $1.74^{* *}$ \\
\hline $\begin{array}{l}\text { Plant reg. } x \\
\text { Hyb. }\end{array}$ & 21 & $0.31^{\text {ns }}$ & $0.41^{\text {ns }}$ & $0.87^{* *}$ & $0.59^{* *}$ \\
\hline $\begin{array}{l}\text { Error } \\
\text { General }\end{array}$ & 64 & 0.25 & 0.34 & 0.35 & 0.19 \\
average & & 9.71 & 3.20 & 4.97 & 1.46 \\
CV (\%) & & 16.50 & 35.84 & 26.78 & 36.56 \\
\hline
\end{tabular}

** F-test significant at $\mathrm{p}<0.01$; ${ }^{\text {ns }}$ non-significant
Table 2. Average number of buds and percentages of oxidized, contaminated and surviving buds obtained from different regions of the plant after in vitro establishment of pineapple hybrids bred for fiber content [FIB-SAI (A. comosus var. bracteatus $x$ A. comosus var. erectifolius), FIB-NEG and FIB-BOY (Ananas comosus. var. microstachys $x$ A. comosus var. erectifolius), FIB-CER, FIB-POT, FIB-MIN, FIB-EST and FIB-ROX (A. comosus var. erectifolius $x$ Ananas comosus var. bracteatus)].

\begin{tabular}{lcccc}
\hline Plant region & $\begin{array}{c}\text { Average } \\
\text { number of buds }\end{array}$ & $\begin{array}{c}\text { Oxidation } \\
(\%)\end{array}$ & $\begin{array}{c}\text { Contamination } \\
(\%)\end{array}$ & Survival (\%) \\
\hline Crown & $20.46 \mathrm{a}$ & $51.90 \mathrm{a}$ & $31.44 \mathrm{c}$ & $16.66(86)^{3} \mathrm{a}$ \\
Lower stem & $5.29 \mathrm{c}$ & $13.42 \mathrm{c}$ & $81.89 \mathrm{a}$ & $4.69(6) \mathrm{b}$ \\
Middle stem & $5.46 \mathrm{c}$ & $12.70 \mathrm{c}$ & $72.38 \mathrm{~b}$ & $14.93(22) \mathrm{a}$ \\
Upper stem & $7.63 \mathrm{~b}$ & $23.40 \mathrm{~b}$ & $61.84 \mathrm{~b}$ & $15.59(26) \mathrm{a}$ \\
\hline Hybrids & & & & \\
\hline FIB-SAI & $9.08 \mathrm{a}$ & $30.27 \mathrm{a}$ & $58.85 \mathrm{~b}$ & $10.88(17) \mathrm{b}$ \\
FIB-NEG & $10.00 \mathrm{a}$ & $13.35 \mathrm{~b}$ & $48.04 \mathrm{~b}$ & $40.28(48) \mathrm{a}$ \\
FIB-BOY & $9.33 \mathrm{a}$ & $50.54 \mathrm{a}$ & $38.82 \mathrm{~b}$ & $10.63(11) \mathrm{b}$ \\
\hline FIB-CER & $9.42 \mathrm{a}$ & $18.64 \mathrm{~b}$ & $80.59 \mathrm{a}$ & $0.78(2) \mathrm{b}$ \\
FIB-POT & $9.83 \mathrm{a}$ & $41.03 \mathrm{a}$ & $51.25 \mathrm{~b}$ & $7.72(7) \mathrm{b}$ \\
\hline FIB-MIN & $8.08 \mathrm{a}$ & $24.84 \mathrm{~b}$ & $70.36 \mathrm{a}$ & $4.80(5) \mathrm{b}$ \\
FIB-EST & $10.25 \mathrm{a}$ & $18.41 \mathrm{~b}$ & $70.41 \mathrm{a}$ & $11.18(12) \mathrm{b}$ \\
FIB-ROX & $11.67 \mathrm{a}$ & $5.75 \mathrm{c}$ & $76.80 \mathrm{a}$ & $17.45(24) \mathrm{b}$ \\
\hline
\end{tabular}

${ }^{1}$ Means followed by the same letters in the column do not differ statistically by the Tukey test at $5 \%$ significancy level; ${ }^{2}$ Means followed by the same letters in the column belong to the same group by the Scott-Knott test at 5\% significancy level; ${ }^{3}$ Values in parentheses represent the absolute numbers of survivors by region and hybrid.

Table 3. Average number of shoots and geometric growth rate in four subcultures of pineapple hybrids from stem and crown buds [FIB-SAI (A. comosus var. bracteatus XA. comosus var. erectifolius), FIB-NEG and FIB-BOY (Ananas comosus. var. microstachys $\times$ A. comosus var. erectifolius), FIB-CER, FIB-POT, FIB-MIN, FIB-EST and FIB-ROX (A. comosus var. erectifolius X Ananas comosus var. bracteatus)].

\begin{tabular}{|c|c|c|c|c|c|c|c|c|}
\hline \multirow{2}{*}{ Hybrid } & \multicolumn{4}{|c|}{ Average number of shoots } & \multicolumn{4}{|c|}{ Geometric growth rate } \\
\hline & S1 & $\mathrm{S} 2$ & S3 & S4 & $\mathrm{S} 1-\mathrm{S} 2$ & $\mathrm{~S} 2-\mathrm{S3}$ & S3-S4 & S1-S4 \\
\hline \multicolumn{9}{|l|}{ Stem } \\
\hline FIB-NEG & 2.00 & 4.15 & 10.94 & 32.53 & 1.64 & 2.18 & 2.45 & 2.09 \\
\hline FIB-POT & 1.75 & 0.00 & 0.00 & 0.00 & - & - & - & - \\
\hline FIB-MIN & 1.67 & 3.92 & 9.25 & 33.08 & 1.92 & 1.93 & 2.87 & 2.24 \\
\hline FIB-EST & 1.00 & 1.50 & 3.00 & 14.50 & 0.91 & 1.55 & 3.56 & 2.00 \\
\hline FIB-ROX & 1.78 & 2.00 & 3.33 & 7.89 & 0.26 & 1.14 & 1.93 & 1.11 \\
\hline \multicolumn{9}{|l|}{ Crown } \\
\hline FIB-SAI & 2.00 & 2.67 & 7.83 & 26.67 & 0.64 & 2.42 & 2.76 & 1.94 \\
\hline FIB-NEG & 1.45 & 1.98 & 5.48 & 15.87 & 0.70 & 2.29 & 2.39 & 1.79 \\
\hline FIB-BOY & 2.00 & 2.00 & 6.17 & 34.67 & 0.00 & 2.53 & 3.91 & 2.14 \\
\hline FIB-CER & 1.00 & 1.00 & 1.00 & 2.00 & 0.00 & 0.00 & 1.55 & 0.51 \\
\hline FIB-POT & 1.00 & 0.00 & 0.00 & 0.00 & - & - & - & - \\
\hline FIB-MIN & 2.00 & 5.00 & 13.00 & 73.00 & 2.06 & 2.15 & 3.91 & 2.70 \\
\hline FIB-EST & 1.50 & 3.00 & 17.00 & 47.50 & 1.55 & 3.93 & 2.31 & 2.59 \\
\hline FIB-ROX & 1.80 & 2.20 & 6.98 & 17.81 & 0.45 & 2.59 & 2.10 & 1.71 \\
\hline
\end{tabular}


FIB-POT, mainly because of the losses due to oxidation of the buds from the two explant sources (stem and crown).

The geometric growth rate tended to increase until the third sub-culture and then showed a substantial reduction in the propagation potential in the fourth sub-culture for all the hybrids except FIB-EST from crown buds (Table 3). This behavior can be described by a quadratic function, generally better adapted for biological processes. Therefore, although the number of shoots increased as the number of sub-cultures progressed, there was a clear reduction of the propagation potential of the hybrids.

The regression model of average number of shoots among sub-cultures showed the effect of genotype on the number of shoots over time. The Poisson log-linear model provided the best fit for the data to represent the multiplication rate of the hybrids for the two explant sources (stem and crown) (Figure 2). The regression showed that the hybrids attained different shoot production peaks over time. The crown buds produced a greater number of shoots from the third subculture for almost all the hybrids, especially FIB-MIN, which had an exponential behavior (Figure 2).

\section{DISCUSSION}

\section{Establishment phase}

The evaluation of explant origin by plant regions (crown and three stem regions) allowed us to evaluate the behavior of buds in the initial phase, and estimate the quantity of viable
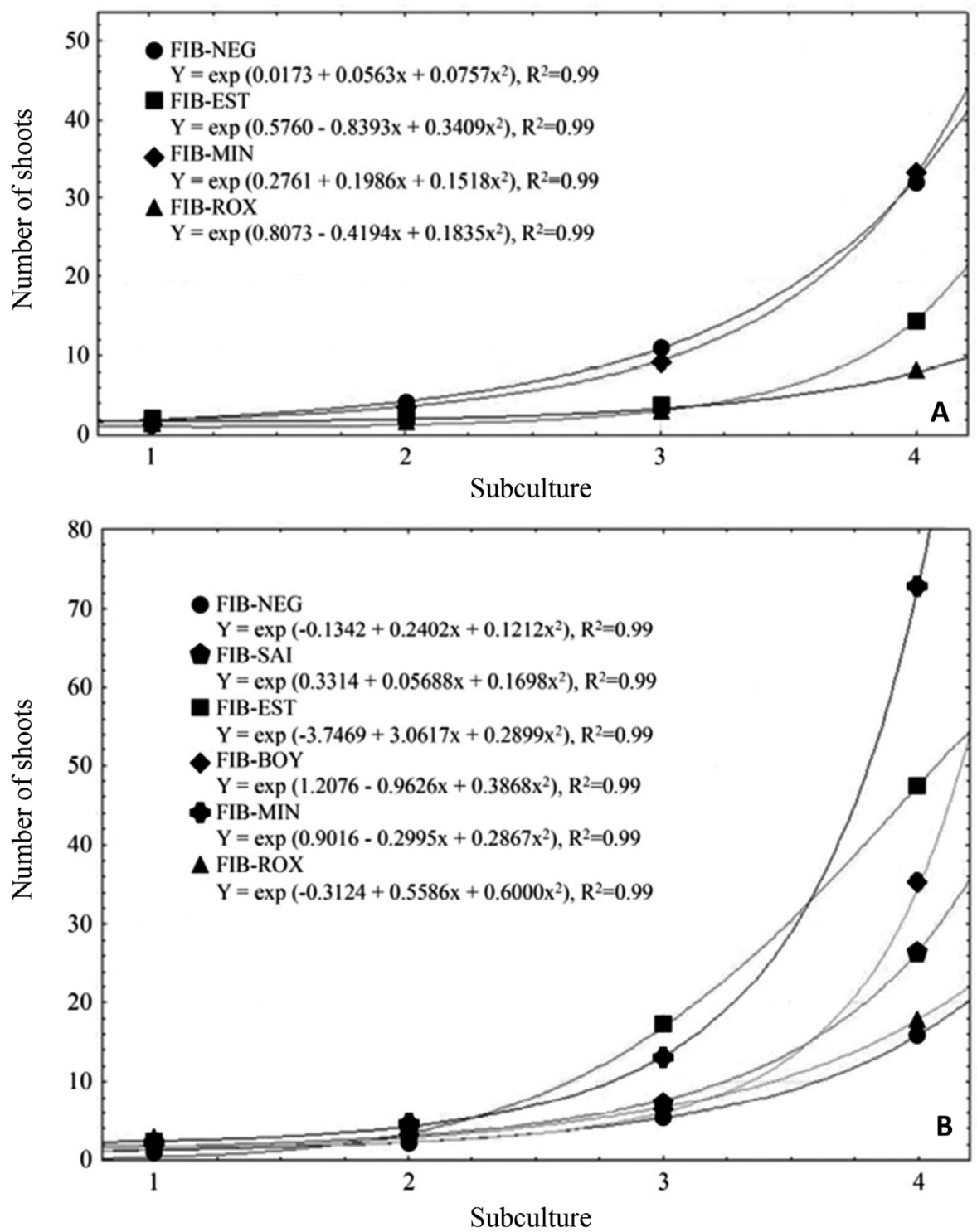

Figure 2. Average number of shoots from stem buds (A) and crown buds (B) of pineapple hybrids in function of the four sub-culture periods. 
buds that can be obtained from the hybrids. The total number of buds produced by a plant can be an indication of its in vivo propagation potential (Silva et al. 2016), even though in laboratory conditions (in vitro), various factors can affect the development of the buds during the culture phase, such as contamination, oxidation and the response to the culture medium (Souza et al. 2013).

Higher oxidation rates in the crown buds during the establishment phase can be attributed to the small size of these buds, which makes manipulation more difficult and may increase the possibility of causing lesions to the tissues during the excision process, causing greater release of polyphenols (Sedighi et al. 2014). The high concentration of phenolic compounds in the site of the lesion may lead to alteration of the medium culture and interfere with the absorption of nutrients by the explants (Andrade et al. 2000; Sedighi et al. 2014). The phenolic compounds are oxidized by the polyphenol enzymes, producing toxic substances that inhibit the growth of the explants, possibly causing their death (Sato et al. 2001; Ozyigit et al. 2007).

In general, stem buds were more susceptible to contamination than crown buds. Under field conditions, the stem is near the soil, in direct contact with microorganisms that can be difficult to remove and/or be resistant to the disinfestation process in the laboratory (Souza et al. 2013). The control of contamination during the in vitro establishment depends on the protocol used. Our results revealed the need to improve the disinfestation procedure in the Embrapa protocol, not only for the buds from the lower part of the stem, but for those from all regions. In addition, the high losses to contamination in the parts closer to the soil may also be related to the fact that the lower tissue was old and hardened, making removal of microorganisms more difficult due to the lesser penetration of disinfectant agents.

The in vitro response of a plant depends on various factors, such as species, genotype and initial explant. Also, the adjustment of the culture medium is one of the most relevant factors to obtain high multiplication rates and healthy plants (Souza $e t$ al. 2012b). Although the protocol used in here was successfully used with several pineapple varieties, our results revealed the need for adjustments in procedures in the establishment phase, which may be improved with more efficient decontamination treatments, such as higher concentrations of the disinfecting agents or longer treatment time.

\section{Multiplication phase}

The marked differences observed in both crown and stem bud production among the hybrids during the multiplication phase indicated a great influence from genotype and the origin of explants on the response to the tested protocol. The effect of genotype has been reported in various studies of micropropagation (Souza et al. 2012b; Alves et al. 2014) and explains the need for constant adjustments of protocols.
Several studies have investigated the in vitro multiplication of different pineapple cultivars, using MS culture medium with different hormonal balances, or in cultivars for food use (Escalona et al. 1999; Piza et al. 2001; Dal Vesco et al. 2001; Macêdo et al. 2003; Carvalho et al. 2005; Silva et al. 2007; Moraes et al. 2010; Souza et al. 2013; Alves et al. 2014) and for ornamental purposes (Borges et al. 2003; Carvalho et al. 2005; 2009; Pasqual et al. 2008, Souza et al. 2013; Alves et al. 2014). BAP, a synthetic cytokinin, is the most used growth regulator for pineapple. For example, in a protocol for the Smooth Cayenne cultivar, the best BAP concentration for the successful multiplication of shoots in the multiplication phase (eight shoots per explant) was of 2 $\mathrm{mg} \mathrm{L}^{-1}$ (Piza et al. (2001). Equilibrated in vitro growth and multiplication rates, i.e., a sufficient number of shoots $(2-5$ shoots after 90 days cultivation), and easy individualization of buds were obtained for the Pérola pineapple cultivar with intermediate concentrations of $0.5 \mathrm{mg} \mathrm{L}^{-1} \mathrm{BAP}+0.25 \mathrm{mg}$ $\mathrm{L}^{-1}$ of NAA and $0.25 \mathrm{mg} \mathrm{L}^{-1} \mathrm{BAP}+0.12 \mathrm{mg} \mathrm{L}^{-1}$ of NAA in MS culture medium (Macêdo et al. 2003). Highest shoot multiplication rates (average of up to 10.4 shoots per explant) for the EMEPA pineapple cultivar were obtained in MS medium supplemented with $2.0 \mathrm{mg} \mathrm{L}^{-1} \mathrm{BAP}+0.5 \mathrm{mg} \mathrm{L}^{-1}$ of NAA during three successive sub-cultures (Moraes et al. 2010). In a study of multiplication of ornamental pineapple, the highest shoot production rate was obtained for A. comosus var. bracteatus (average 12.30 shoots per explant) at a BAP concentration of $3 \mathrm{mg} \mathrm{L}^{-1}$, while $A$. comosus var. erectifolius only yielded 4.60 shoots per explant (Alves et al. 2014).

The culture system used in this this work involved a solid medium (2.5 $\mathrm{g} \mathrm{L}^{-1}$ of Phytagel $\left.)^{\circ}\right)$ with concentrations of $0.5 \mathrm{mg} \mathrm{L}^{-1}$ of BAP and $0.2 \mathrm{mg} \mathrm{L}^{-1}$ of NAA. Under these conditions, after 90 days, the hybrid FIB-NEG produced the largest average number of shoots, considering the starting explant from the stem, and the hybrid FIB-MIN produced an average of 5 shoots when the starting explant was from the crown. These numbers are low if compared with the results described above with the varieties of Ananas comosus var. comosus, but are similar to those obtained with Ananas comosus var. erectifolius, which is one of the parents of the hybrids evaluated in this work. Increasing the multiplication rates and the propagation potential of the hybrids evaluated can be obtained through more radical adjustments to the Embrapa protocol. Bud production can be improved by testing new hormonal balances, or increasing the intervals of subcultures. The subculture interval appears to have an influence on multiplication rates (Hamad and Taha 2008).

In micropropagation of banana plants, the application of the derivative of each fitted regression model allowed to identify the temporal transition from a positive peak to the decrease in the multiplication rate, thus, although the number of shoots continued to increase, the propagation potential declined after a peak yield point (Mendes et al. 1999). A 
similar result was reported by Silva et al. (2016) for different wild pineapple accessions, with most materials peaking production in the fourth sub-culture, followed by decline in the fifth sub-culture. The causes of this decrease are varied and need to be studied more thoroughly, but the interval determined for subculture might have a strong influence on the result (Hamad and Taha 2008).

A relevant contribution of this study is the adequacy of the statistical tools used for in vitro biological models. As already established by Silva et al. (2016), the use of geometric growth rates in this case resulted in the estimation of more realistic multiplication rates for plants grown in vitro, which should allow for better projections of propagation potential and behavior patterns during successive sub-cultures. Other studies have demonstrated that the in vitro multiplication behavior of plants tends to follow a quadratic model, with decline of the multiplication rates after attaining a peak at a determined number of sub-cultures (Mendes et al. 1999; Hamad and Taha 2008).

\section{CONCLUSIONS}

The curuá pineapple hybrid FIB-NEG presented the best result in the initial establishment phase using the protocol developed by Embrapa Mandioca e Fruticultura, attaining the highest survival percentages among eight hybrids tested. The best multiplication rates were obtained from crown buds, with the highest values being recorded for FIB-EST, FIB-MIN and FIB-BOY, and in the fourth sub-culture. Our results demonstrate that it is possible to obtain shoots of curauá pineapple hybrids by micropropagation applying the standard protocol used at Embrapa. In general, all the hybrids presented low multiplication rates in comaprison with other varieties, which indicates that further studies are needed to adjust the protocol to the specific requirements of these hybrids.

\section{ACKNOWLEDGMENTS}

The authors acknowledge the support of Fundaçáo de Amparo à Pesquisa do Estado da Bahia, Conselho Nacional de Desenvolvimento Científico e Tecnológico - CNPq, and Coordenaçấo de Aperfeiçoamento de Pessoal de Nível Superior - CAPES (Edital CAPES-EMBRAPA 15/2014 and PROCAD 2013) for the scholarships granted.

\section{REFERENCES}

Alves, K.A.; Londe, L.N.; Melo, E.F.; Rodrigues, G.B. 2014. Multiplicação de abacaxizeiros ornamentais em diferentes concentraçóes de BAP e períodos de avaliaçáo do desenvolvimento in vitro. Bioscience Journal, 30: 188-198.

Andrade, M.W.; Luz, J.M.Q.; Lacerda, A.S.; Melo, P.R.A. 2000. Micropropagation of urunday (Myracrodruon urundeuva Fr. All). Ciência e Agrotecnologia, 24: 174-180.
Asim, M.; Abdan, K.; Jawaid, M.; Nasir, M.; Dashtizadeh, Z.; Ishak, M.R.; Hoque, M.E. 2015. A review on pineapple leaves fibre and its composites. International Journal of Polymer Science, Article ID 950567.

Borges, N.S.S.; Correia, D.; Rossetti, A.G. 2003. Influência do meio bifásico na multiplicação de gemas e no alongamento de brotos in vitro de Ananas lucidus Miller. Revista Brasileira de Horticultura Ornamental, 9: 37-44.

Carvalho, A.C.P.P.; Braga, E.P.; Santos, M.R.A.; Morais, J.P.S. 2005. Micropropagaçáo de abacaxi ornamental (Ananas comosus var. bracteatus) por meio da indução ao estiolamento e regeneração de plântulas. Revista Brasileira de Horticultura Ornamental, 11: 121-126.

Carvalho, A.C.P.P.; Pinheiro, M.V.M.; Dias, G.M.G.; Morais, J.P.S. 2009. Multiplicação in vitro de abacaxi ornamental por estiolamento e regeneração de brotações. Horticultura Brasileira, 27: 103-108.

Dal Vesco, L.L.; Pinto, A.A.; Zaffari, G.R.; Nodaria, R.O.; Reis, M.A.; GUERRA, M.P. 2001. Improving pineapple micropropagation protocol through explant size and medium composition manipulation. Fruits, 56: 143-154.

Escalona, M.; Lorenzo, J.C.; González, B.; Daquinta, M.; González, J.L.; Desjardins, Y.; Borroto, C.G. 1999. Pineapple (Ananas comosus L. Merr) micropropagation in temporary immersion systems. Plant Cell Reports, 18: 743-748.

Hamad, A.M.; Taha, R.M. 2008. Effect of sequential subcultures on in vitro proliferation capacity and shoot formations pattern of pineapple (Ananas comosus L. Merr.) over different incubation periods. Scientia Horticulturae, 117: 329-334.

Leão, A.L.; Machado, I.S.; Souza, S.F.; Soriano, L. 2009. Production of curauá (Ananas erectifolius L.B. Smith) fibers for industrial applications: characterization and micropropagation. Acta Horticulturae, 822: 227-238.

Macêdo, C.E.C.; Silva, M.G.; Nóbrega, F.S.; Martins, C.P.; Barroso, P.A.V.; Alloufa, M. A. I. 2003. Concentraçóes de ANA e BAP na micropropagação de abacaxizeiro 1. Merrill (Ananas comosus) e no cultivo hidropônico das plântulas obtidas in vitro. Revista Brasileira de Fruticultura, 25: 501-504.

Marinelli, A.L.; Monteiro, M.R.; Ambrósio, J.D.; Branciforti, M.C.; Kobayashi, M.; Nobre, A.D. 2008. Desenvolvimento de compósitos poliméricos com fibras vegetais naturais da biodiversidade: uma contribuição para a sustentabilidade amazônica. Polímeros: Ciência e Tecnologia, 18: 92-99.

Mendes, B.M.J.; Filippi, S.B.; Demétrio, C.G.B.; Rodriguez, A.P.M. 1999. A statistical approach to study the dynamics of micropropagation rates, using banana (Musa spp.) as an example. Plant Cell Reports, 18: 967-971.

Moraes, A.M.; Almeida, F.A.C.; Bruno, R.L.A.; Cazé Filho, J.; Nunes, S.T.; Gomes, J.P. 2010. Micropropagação de abacaxizeiro cv. Emepa 1. Revista Brasileira de Engenheria Agricola Ambiental, 14: 932-936.

Murashige, T.; Skoog, F. 1962. A revised medium for rapid growth and bioassays with tobacco tissue cultures. Physiologia Plantarum, 15: 473-497.

Ozyigit, I.I.; Kahraman, M.V.; Ercan, O. 2007. Relation between explant age, total phenols and regeneration response of tissue 
cultured cotton (Gossypium hirsutum L). African Journal of Biotechnology. 6: 3-8.

Pasqual, M.; Santos, F.C.; Figueiredo, M.A.; Junqueira, K.P.; Rezende, J.C.; Ferreira, E.A. 2008. Micropropagação do abacaxizeiro ornamental. Horticultura Brasileira, 26: 45-49.

Pereira, F.D.; Pinto, J.E.B.P.; Rodrigues, H.C.A.; Rosado, L.D.S.; Beijo, L.A.; Lameira, O.A. 2006. Proliferação in vitro de brotos de curauá utilizando diferentes volumes de meio de cultura. Plant Cell Culture \& Micropropagation, 2: 102-106.

Pereira, F.D.; Pinto, J.E.B.P.; Rodrigues, H.C.A.; Rosado, L.D.S.; Beijo, L.A.; Lameira, O. 2007. Caracteres anatômicos de fibras foliares de brotaçóes de curauá propagadas in vitro. Acta Scientiarum - Biological Sciences, 29: 23-28.

Piza, I.M.T.; Lima, G.P.P.; Brasil, O.G. 2001. Reguladores vegetais na micropropagação do abacaxizeiro. Revista Ceres, 48: 681-690.

R Development Core Team. 2017. R: A Language and Environment for Statistical Computing. R Foundation for Statistical Computing, Vienna, Austria. (https://www.r-project.org/). Accessed on 18/09/2017.

Rocha, J.S.; Pontes, C.L.F.; Câmara, V.M.O; Ramos, K.B.L.; Bessa, T.M.F. 2013. Aproveitamento de fibras vegetais para a construção sustentável. Inclusão Social, 6: 42-47.

Santos, P.B.; Barbosa, F.S.; Vieira, C.F.; Carvalho, A.C.P.P. 2015. Número de explantes, meio de cultura e fotoperíodo na micropropagação de abacaxizeiro ornamental. Revista Ciência Agronômica, 46: 749-754.

SAS Institute Inc. 2010. SAS/STAT 9.22 User's Guide. Cary, NC: SAS Institute Inc. 8460p. (http://support.sas.com/ documentation/cdl/en/7/PDF/default/). Accessed on $15 / 11 / 2010$.

Sato, A.Y.; Dias, H.C.T.; Andrade, L.A.; Souza, V.C. 2001. Micropropagação de Celtis sp.: controle da contaminação e oxidação. Cerne, 7: 117-123.

Sedighi, A.; Sedighi-dehkordi, F.; Gholami, M.; Rafieian-kopaei, M. 2014. Study of the effect of plant growth regulators, size, and cultivar of the grape inflorescence explant on production of phenolic compounds in an in vitro condition. Journal of HerbMed Farmacology, 3: 35-40.

Sena Neto, A.R.S.; Claro, P.I.C.; Souza, F.V.D.; Mattoso, L.H.C. ; Marconcini, J.M. 2017. Poly (lactic acid) composites reinforced with leaf fibers from ornamental variety of hybrid pineapple (Potyra). Polymer Composites, 38: 1228-1235.

Sena Neto, A.R.; Araujo, M.A.M.; Barboza, R.M.P.; Fonseca, A.S.; Tonoli, G.H.D.; Souza, F.V.D.; Mattoso, L.H.C.; Marconcini,
J.M. 2015. Comparative study of 12 pineapple leaf fiber varieties for use as mechanical reinforcement in polymer composites. Industrial Crops and Products, 64: 68-78.

Sena Neto, A.R.; Araujo, M.A.; Souza, F.V.; Mattoso, L.H.; Marconcini, J.M. 2013. Characterization and comparative evaluation of termal, structural, chemical, mechanical and morphological properties of six pineapple leaf fiber varieties for use in composites. Industrial Crops and Products, 43: 529-537.

Silva, A.B.; Pasqual, M.; Teixeira, J.B.; Araújo, A.G. 2007. Métodos de micropropagação de abacaxizeiro. Pesquisa Agropecuária Brasileira, 42: 1257-1260.

Silva, R.L.; Ferreira, C.F.; Ledo, C.A.S.; Silva, P.H.; Souza, E.H.; Costa, M.A.P.C.; Souza, F.V.D. 2016. Viability and genetic stability of pineapple germplasm after ten years of in vitro conservation. Plant Cell, Tissue and Organ Culture, 127: 123-133.

Souza, C.P.F.; Ferreira, C.F.; Souza, E.H.; Sena Neto, A.R.; Marconcini, J.M.; Ledo, C. A.S.; Souza, F.V.D. 2017. Genetic diversity and ISSR marker association with the quality of pineapple fiber for use in industry. Industrial Crops and Products, 104: 263-268.

Souza, E.H.; Costa, M.A.P.C.; Santos-Serejo, J.A.; Souza, F.V.D. 2014. Selection and use recommendation in hybrids of ornamental pineapple. Revista Ciência Agronômica, 45: 409-416.

Souza, E.H.; Souza, F.V.D.; Costa, M.A.P.C.; Costa Junior, D.S.; Santos-Serejo, J.A.; Amorim, E.P.; Ledo, C.A.S. 2012a. Genetic variation of the Ananas genus with ornamental potential. Genetic Resources and Crop Evolution, 59: 1357-1376.

Souza, E.H.; Souza, F.V.D.; Silva, M.J.; Souza, A.S.; Costa, M.A.P.C. 2012b. Growth regulators and physical state of culture media in the micropropagation of ornamental pineapple hybrids. Plant Cell Culture and Micropropagation, 8: 10-17.

Souza, F.V.D.; Souza, A.S.; Santos-Serejo, J.A.; Souza, E.H.; Junghans, T.G.; Silva, M.J. 2013. Micropropagação do Abacaxizeiro e Outras Bromeliáceas. In: Junghans, T.G.; Souza, A.S. (Org.). Aspectos Práticos da Micropropagação de Plantas. 2nd ed. Embrapa Mandioca e Fruticultura Tropical, Brasília, Distrito Federal, p.189-218.

Zah, R.; Hischier, R.; Leão, A.L.; Braun, I. 2007. Curauá fibers in the automobile industry e a sustainability assessment. Journal of Cleaner Production 15: 1032-1040.

RECEIVED: $01 / 02 / 2018$

ACCEPTED: $18 / 07 / 2018$

ASSOCIATE EDITOR: Rosy Mary Isaias 